\title{
Grammaticalization of spatial adpositions in Nànáfwê
}

\author{
Amani Bohoussou and Stavros Skopeteas
}

\section{Introduction}

Typical sources for adpositions across languages are relational nouns and transitive verbs, hence elements that already display an argument slot (see Lehmann 1995b:104). The grammaticalization process is similar in both cases. In case of relational nouns, grammaticalization applies to the dependency between the noun and its head in the clause. While a relational noun may serve as an argument, its adpositional counterpart displays the distributional properties of an adverb (with the difference that it is accompanied by a complement NP). In case of transitive verbs, grammaticalization takes place in serial verb constructions: what was once a part of a verb series, is the dependent of a verbal head after grammaticalization.

It is well known in West African linguistics that languages in this broad area display adpositions that emerge out of these two sources, namely nouns and verbs. The corresponding adpositional elements undergo distinct grammaticalization paths and form sub-paradigms with characteristically distinct semantic and syntactic properties (see Heine, Claudi, and Hünnemeyer 1991: 140-141): (a) V-adpositions form-small size classes, while Nadpositions form large-size classes; (b) V-adpositions typically denote different spatial relations (i.e., static, allative, ablative, perlative, etc.) between the localized object and the reference object of a locative construction, while $\mathrm{N}$-adpositions typically denote different spatial regions of the reference object (e.g., interior, exterior, superior, inferior, etc.); (c) Vadpositions introduce adjuncts, while $\mathrm{N}$-adpositions may introduce either adjuncts or complements. Furthermore, $\mathrm{V}$-adpositions generally follow the ordering rules within VPs, while $\mathrm{N}$-adpositions follow the ordering rules within complex NPs. Hence, in languages like Ewe (Ghana, Togo: Kwa) or Koromfe (Burkina Faso, Mali: Gur), where VPs are head-initial and NPs head-final, two subclasses of adpositions may be distinguished: prepositions, which emerge out of verbs, and postpositions, which emerge out of 
nouns (see Heine and Reh 1984: 253-258, Heine, Claudi, and Hünnemeyer 1991: 142ff. for Ewe, see Rennison 1997: 169ff. for Koromfe).

In this paper, we present evidence for the emergence of spatial adpositions in Nànáfwê, which is a dialect of Baule, a language of the Kwa branch of the Niger-Congo family. It is spoken in the central part of Côte d'Ivoire in the district of Yamoussoukro by a population of approximately 15000 speakers. The grammatical properties of Baule have been the subject of several publications including descriptive grammars (Carteron 1966, Creissels and Kouadio 1977, Timyan 1977) and numerous publications on phonology (Gross 1967, Creissels and Kouadio 1979, Ahoua 1996, Leben and Ahoua 1997 among others) and syntax (Larson 2002, 2005, Kouadio 2000, Kouadio and Creissels 2007 among others) (see a bibliographical outline in Bohoussou 2008). The particular variety of Baule that we examine in this paper is virtually unexplored. A few recent works on this dialect shed light on the syntax of the simple clause (Bohoussou 1996), on clause linkage (Bohoussou 2008), and on copulative constructions (Bohoussou and Skopeteas 2005). An outline of the basic grammatical properties of Nánàfwê is given in section 2 .

The data from Nànáfwê adpositions is very similar to the data reported from other West African languages. It is clear that a particular class of nouns and a small set of verbs occur as heads of NPs forming a constituent that may be used as verb dependent, i.e. in a syntactic function in which we expect to find an adpositional phrase. Similarly to Ewe and Koromfe, adposition-like elements that originate in nouns form head-final constituents as exemplified in (1a), while adposition-like elements that originate in verbs form head-initial constituents as exemplified in (1b). We refer to the two classes of elements as $\mathrm{N}$-relators and V-relators without anticipating their grammaticalization status which is the empirical question of this paper. The term 'relator' is used with functional content, indicating the exponent of a component of a localizing function (see Lehmann 1992).

a. N-relator

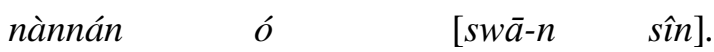

grandfather be.located house-DEF back.side ${ }^{1}$

'The grandfather is behind the house.'

b. V-relator

nànnán wàndí [kó dímbókrô].

grandfather run go Dimbokro

'The grandfather runs to Dimbokro.' 
The data presented in (1) is not enough to conclude that the relational elements are grammaticalized. A grammaticalization process is not implied by the occurrence in a particular syntactic function but has to be diagnosticized through a set of heuristics (outlined in Lehmann 1995b, see introduction to this volume) that reflect a change in the distributional properties of the elements at issue. With this conceptual background, the aim of the current contribution is descriptive: we examine two classes of elements in Nànáfwê that are usually involved in grammaticalization processes across languages, and we address the question whether the available evidence from this language suggests such a diachronic process.

Sections 3 and 4 present the main body of the empirical evidence providing a detailed account of N-relators and V-relators, respectively. Our account primarily relates to the syntactic phenomena applying to locative constructions; we will refer to the abstract uses of adpositions only when these are relevant for the syntax. Section 5 summarizes the differences between $\mathrm{N}$-relators and V-relators and section 6 draws the conclusions of this empirical study with respect to grammaticalization.

\section{Basic grammatical properties of Nànáfwê}

Most syntactic structures in Nànáfwê are head-initial. Verbs precede complements and adjuncts and are preceded by the subject constituent rendering a rigid SVOAdv order, which is exemplified in (2a) for temporal adverbs and in (2b) for manner adverbs that are VP-internal and display different word order properties in some languages (see, e.g., manner adverbs in Edo, Stewart 2001: 20). Temporal or local adjuncts may be leftdislocated in which case they serve as frame setters, see (2c).
a. nànnán tóntòn-ní dwó-n nné. grandfather cook-PFV yam-DEF today 'The grandfather cooked the yam today.'

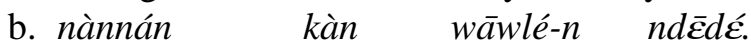 grandfather speak baule-DEF rapidly 'The grandfather speaks Baule rapidly.'
c. nné nànnán tóntòn-ní dwó-n.
today grandfather cook-PFV yam-DEF
'Today, the grandfather cooked the yam.'


Nouns precede adjectival modifiers and quantifiers as illustrated in (3a), while the definite determiner is a suffix, as shown in ( $3 b)$ and ( $3 c)$. In contrast, pronominal and nominal dependents precede the head NP, as demonstrated in (3b) and (3c), respectively.
a. tràlé blê njòn
shirt blue/black/green four 'four blue/black/green shirts'
b. mí tràlé-n
1.SG shirt-DEF
'my shirt'
c. kòfí tràlé-n
Kofi shirt-DEF
'the shirt of Kofi'

The word order facts are summarized in (4). The facts that verbs precede their complements and adjuncts, and that nouns precede their modifiers lead to the generalization that heads precede their dependents in (4a). An apparent exception to this generalization is that possessor NPs precede possessed NPs in (4b). Finally, subjects precede predicates.
(4) a. head
$\prec$ dependent
b. $\mathrm{NP}_{\text {dependent }}$
$\prec \mathrm{NP}_{\text {head }}$
c. subject
$\prec$ predicate

Syntactic relations generally do not have morphological exponents: Nouns do not inflect for case and verbs do not bear agreement affixes, as may be observed in (2). Argument functions are unambiguously encoded by linear order. Subject constituents have to be overtly realized (see Creissels and Kouadio 2007: 3), while object constituents have to be dropped under particular circumstances (object drop occurs with a lexically conditioned subset of verbs; with these verbs, inanimate singular referents in clause final position that may be contextually retrieved cannot be overtly realized, see Larson 2002: 90).

Verbal inflection in Nànáfwê comprises a number of affixes that encode aspectual/temporal/modal distinctions. Some of them are suffixes as illustrated in (5a) by means of the perfective, while others are independent morphemes that are anteposed to the lexical verb, as shown in (5b) by means of 
the progressive. The latter elements are diachronically derived from serial verb constructions (see Larson 2002).
a. kòfí nántì-lí.
Kofi walk-PFV
'Kofi walked.'
b. kòfí sú nàntí.
Kofi PROG walk
'Kofi is walking.'

Nouns are not inflected. The only morpheme that occurs with nouns is an enclitic that conflates definiteness and number (singular vs. plural) that is attached at the right edge of the NP constituent (see Bohoussou 2008: 21).

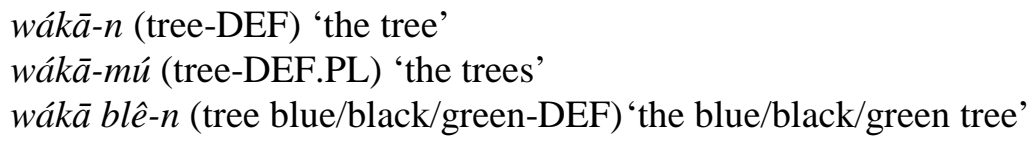

Personal pronouns display a contrast between independent and cliticized forms which are segmentally different in the singular': $m i$ ' 1 .SG' vs. $n$ '1.SG.SBJ.CL', wó '2.SG' vs. a '2.SG.SBJ.CL', and $i$ '3.SG' vs. 0 '3.SG.SBJ.CL' (see Bohoussou 2008: 23). Cliticized forms do not bear lexical tone: their tonal properties are determined by the tonal structure of the verb (see Creissels and Kouadio 2007: 3). Independent pronouns occur in object function or as possessors of NPs, as illustrated in (7a-b).
a. kòfí wùn-ní i nné.
Kofi see-PFV 3.SG today
'Kofi saw him today.'
b. $i \quad s w \bar{a}-n$
3.SG house-DEF
'his house'

When the possessor is realized in a lexical NP, the possessive pronoun may occur also. The pronominal expression is optional in singular (see $(8 a-b))^{3}$.

(8) a. nànnán i swā-n grandfather 3.SG house-DEF 'the house of the grandfather' 
$\begin{array}{ll}\text { b. nànnán } & s w \bar{a}-n \\ \text { grandfather } & \text { house-DEF }\end{array}$

Cliticized pronouns occur in subject function, when the subject constituent is contextually retrievable and non-emphatic. The reference of the $3^{\text {rd }}$ person clitic pronoun in (9a) may not identify a referent in the discourse situation (as a demonstrative), but is co-indexed with a contextual antecedent. The subject clitics are obligatory, when the lexical subject is left dislocated rendering a clitic doubling construction, as illustrated in (9b).
a. $\grave{\jmath}$
wùn-ní
kòfí
3.SG.SBJ.CL see-PFV Kofi
'He saw Kofi.'
b. nànnán jò wùn-ní kòfí
grandfather 3.SG.SBJ.CL see-PFV Kofi
'The grandfather ${ }_{i}$, he $_{i}$ saw Kofi.'

In sum, the major grammatical properties of Nànáfwê, that are presented in this section, are: (a) word order is generally head-initial; (b) possessor NPs precede possessed NPs and may be optionally cross-referenced by a co-indexed pronoun; (c) inflection is poor and does not involve encoding of syntactic relations; (d) pronouns display a contrast between independent and clitic forms, whereby the distribution of the latter is restricted to the subject function. With this grammatical background, we discuss evidence concerning locative relational morphemes in the next sections.

\section{N-relators}

\subsection{Preliminaries}

The diachronic change from nouns to adpositions implies an initial grammatical stage which involves two noun phrases, $\mathrm{NP}_{1}$ and $\mathrm{NP}_{2}$ as illustrated in (10), stage $S_{1} \cdot \mathrm{NP}_{1}$ is the head of this constituent, $\mathrm{NP}_{2}$ is an optional dependent of $\mathrm{NP}_{1}$, and both form a complex NP, whereby the order of constituents in (10) does not relate to the realized word order (both $\mathrm{NP}_{1} \prec \mathrm{NP}_{2}$ and $\mathrm{NP}_{2} \prec \mathrm{NP}_{1}$ are possible and depend on language-specific word order rules). The target grammatical stage $S_{2}$ involves two changes. First, the entire constituent is an AdpP and not an NP anymore; this change implies 
some differences in the distribution of this constituent in syntactic constructions. Second, $\mathrm{NP}_{1}-$ or the $\mathrm{N}$ contained within $\mathrm{NP}_{1}-$ has turned to an adposition, i.e. $\mathrm{NP}_{2}$ is not an optional dependent anymore, but is the complement of the adposition.

(10) $\quad$ a. $\quad$ stage $S_{1}: \quad\left[\begin{array}{lll}\mathrm{NP} & \mathrm{NP}_{1} & \mathrm{NP}_{2}\end{array}\right]$

b. stage $S_{2}: \quad$ [AdpP Adp NP]

c. $\quad S_{1}>S_{2}$

It is important to bear in mind that the sketched grammaticalization process involves two syntactic changes, which may well be independent from one another. The first change relates to the distributional properties of the entire constituent, i.e., to the syntactic relation between the head of this constituent and its head in the clause, while the second relates to the syntactic relation between head and dependent within the constituent at issue.

Evidence for this development in Nànáfwê is found in a (semantically defined) set of nouns that encode parts of spatial configurations (henceforth, locative nouns). In line with the ' $\mathrm{NP}_{\text {dependent }} \prec \mathrm{NP}_{\text {head }}$ ' ordering principle, the locative noun follows the noun that encodes the reference object. As already observed for possessive constructions in (8), the reference object is optionally cross-referenced by a co-indexed element of the class of independent pronouns.

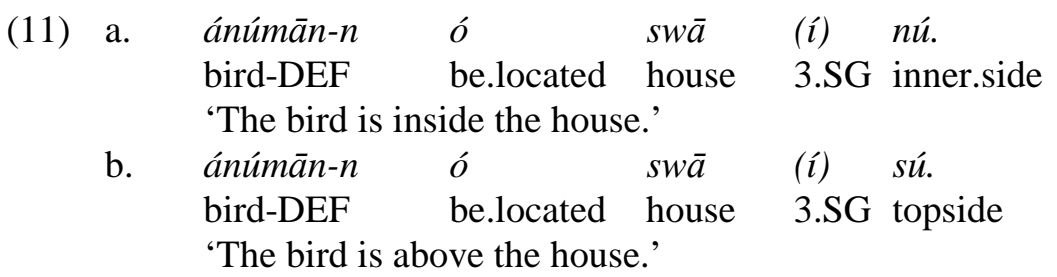

As already implied by the contrast between (11a) and (11b), there is a set of locative nouns that may be used in this construction. The exponents of the basic oppositions are given in Table 1. 
Table 1. N-relators in Nànáfwê

\begin{tabular}{ll}
\hline spatial region & noun \\
\hline interior & nú \\
superior & sú \\
inferior & bố \\
anterior & frún \\
posterior & sîn \\
lateral & nwán \\
dextral & fámānú \\
sinistral & bēnú \\
\hline
\end{tabular}

There is ample evidence from grammaticalization studies that locative nouns encoding parts of spatial configurations such as those exemplified in Table 1 develop into adpositions in several languages (see among others Heine 1989: 88, Lehmann 1990: 172, Heine, Claudi, and Hünnemeyer 1991: 129, Svorou 1993: 70, Rubba 1994: 86, Lehmann 1995b: 77). A frequently reported semantic change is concomitant to the syntactic changes in (10). While the nouns denote parts of spatial configurations, typically body parts, the derived adpositional elements denote spatial regions, i.e., fragments of space that are determined either by their contiguity to particular parts of the reference object (for instance the spatial region denoted by the English preposition on is contiguous to the top part of the reference object) or by axes projected by these parts (for instance the spatial region denoted by the English preposition above contains possible locations on the axis projected to the top part of the reference object).

In the following sections, we discuss the categorical status of the locative nouns in Nànáfwê. We first discuss the syntactic properties of the entire constituent in section 3.2. Section 3.3 outlines the syntactic relation between the parts of this constituent.

\subsection{Syntactic properties of the locative constituent}

The evidence that the elements listed in Table 1 are nouns is syntactic. All these elements also occur in argument functions as illustrated by means of the noun $n u ́$ 'inside' in (12a). From a semantic viewpoint, example (12a) shows that the exponents of spatial region are referential in Nànáfwê, i.e. they may be used to denote a particular part of the spatial configuration of 
the dependent NP's referent. Furthermore, as a noun it may be modified by adjectives as illustrated in (12b).
a.
$s w \bar{a}-n$
sú
tí blê.
'The topside of the house is blue/black/green.'
b. swā-n sú klánmān tí blê.
house-DEF topside beautiful-DEF be blue/black/green
'The beautiful topside of the house is blue/black/green.'

The categorical status of these nouns when they occur in the locative construction in (11) is at issue. The thematic properties of these elements, i.e., their role as locative constituents, are not encoded by the noun itself or its position, but by the verb. Note that the verb o 'be.located' in (11) is a locative verb, while property assignment is either expressed through a zero copula or through the linking element $t i$ ' $b e$ '. Hence, the thematic role of location is carried by the verbal valency and does not imply a change in the categorical status of these elements in the first sight. Moreover, we observe that further nouns are eligible arguments for the locative copula $o$ 'be.located', as shown in (13a). The same phenomenon is illustrated in (13b) by means of a verb of motion and common nouns.
a. ánúmān-n ó dímbókrô. bird-DEF be.located Dimbokro 'The bird is in Dimbokro.'
b. ń kó sùklū-nl klō-n.
1.SG.SBJ.CL go school-DEF village-DEF
'I will go to the school/the village.'

Further evidence that the thematic properties of these elements are determined by the verb is the fact that they are not specified for spatial relation. Hence, the distinction between static and different subtypes of dynamic (i.e., allative, ablative, perlative) spatial relations is specified completely through the verbal valency. Example (14a) illustrates the thematic underspecification by means of a motion verb and an N-relator, (14b) by means of a motion verb and a proper noun, and (14c) by means of a verb of transport and an N-relator. This phenomenon is very widespread in languages that denote spatial regions through locative nouns, and by no means re- 
stricted to this language type (see facts from Koromfe in Rennison 1997: 173, and from Yucatec Maya in Lehmann 1992: 636, 1995a).
a.
$k \grave{f} \hat{\imath}$
kól fin/
$\sin \quad s w \bar{a}-n$
nú.
Kofi go leave pass house-DEF inner.side

(literally) 'Kofi goes into the house/leaves from inside the house/passes through the house.'
b.
kòfí
kól fin/
sìn dímbókrô nú.
Kofi
go leave
pass Dimbokro inner.side

(literally) 'Kofi goes into Dimbokro/leaves from inside Dimbokro /passes through Dimbokro.'
c. kòfi fìn bútèlí-n bjá-n sú.
Kofi put bottle-DEF chair-DEF topside
'Kofi puts the bottle on the chair.'

The occurrence of nouns in this construction and their thematic underspecification suggest that locative verbs do not put categorical restrictions on their complements. However, this is the wrong conclusion: first, not every noun is eligible in this construction but only nouns that denote places. Second, locative verbs differ from transitive verbs in that they may take an adverbial complement. The deictic adverbs 'here' and 'there' may fill the argument slot of a locative verb as exemplified in (15), but not the argument slot of a transitive verb.

$$
\begin{aligned}
& \text { kòfi kól fin/ } \sin l \dot{\varepsilon} . \\
& \text { Kofi go leave pass there } \\
& \text { (literally) 'Kofi goes there/leaves from there/passes through } \\
& \text { there.' }
\end{aligned}
$$

Assuming that locative verbs license an adverbial complement with the thematic properties of place (unspecified for the exact spatial relation), the restriction to nouns denoting places is expected. Only those nouns that may be reinterpreted as adverbial expressions of place may occur in this construction. Locative nouns may occur as complements of locative verbs, but they display a distributional peculiarity: In contrast to their referential use, locative nouns may not be accompanied by adjectival modifiers in their use as adpositions. Hence, the ungrammaticality of (16) contrasts to the grammaticality of (12b). Note that the availability of a pronominal possessor does not interact with the grammaticality of this structure. 
(16)
a. $\quad * k o ̀ f i \quad o ́$
$s w \bar{a}-n$
(i) sú
klánmān.
Kofi be.located house-DEF 3.SG topside beautiful (intended) 'Kofi is at the beautiful topside of the house.'
b. *ánúmān-n ó swā (i) nú blê.
bird-DEF be.located house 3.SG blue/black/green (intended) 'The bird is at the blue/black/green inner side of the house.'

In concluding, distributional criteria suggest that locative nouns in their use as complements of locative verbs are in the incipient stage of a grammaticalization process. The critical restriction is their capability to occur with adjectival modifiers, which is a possible syntactic configuration outside the locative constructions (compare similar evidence concerning postpositions in Ewe in Heine and Reh 1984: 257).

\subsection{Head-dependent relation}

This section examines the syntactic relation between the head and the governed noun in the locative construction. Svorou (1986) points out that a critical point in the development of adpositions out of nouns is the loss of relational morphology (e.g., genitive affixes). The relevant issue in Nànáfwê is the behavior of the pronominal markers in the context of nounto-noun dependencies. We have already mentioned that pronominal possessors are optional with most nouns (see (8c-d)), and so do they with locative nouns too (see (11a) and (11b)). The question is whether this alternation is functionally vacuous (hence, free variation) or reflects a semantic opposition.

In a compositional view, the occurrence of a possessive pronoun is expected to indicate a possessive relation between the locative noun and the dependent noun. The construction without a locative pronoun is expected to be underspecified in this respect. Keeping in mind the compositional predictions, we observe some critical examples in the following. The sentences in (17a) and (17b) are only partly synonymous: The version in (17a), without a co-indexed pronominal, denotes that the localized object is located in the spatial region that is projected by the backside of the reference object, i.e. behind it. However, the version in (17b), with a pronominal possessor, has an additional reading: it may denote that the localized object is located within the part of the spatial configuration of the reference 
object that is referred to as 'back part'. The latter meaning is exactly the expected compositional reading of the construction with a pronominal possessor. The assertion of the possessive relation through the pronoun licenses a reading in which a meronomic (part-whole) relation holds between the two nouns. Note that the unspecified version is (17b), i.e., the version with the pronominal possessor.
a. kòfí ó
$s w \bar{a}-n$
sîn.
Kofi be.located house-DEF back.side
'Kofi is behind the house.'
*'Kofi is at the back part of the house.'
b. kòfi ó swā-n $n$ sin.
Kofi be.located house-DEF 3.SG back.side
'Kofi is behind the house.'I
'Kofi is at the back part of the house.'

Similar minimal pairs occur with further adpositions as well. The noun sú 'on/above' denotes superposition in the vertical axis. In the version (18a) without pronominal possessor, the localized object is located in this axis; due to inferences that relate to the posture verb fin 'stand' and world knowledge, this example is interpreted as involving contact to the upper side of the reference object, but this inference is defeasible (see Skopeteas 2007). The version (18b) with pronominal possession is semantically different: the possessive morphology licenses the interpretation of a partwhole relation between the denoted region 'on/above' and the reference object. This is not necessarily the same location, depending on the spatial configuration of the chair.
bútèlí-n fín bjá-n sú.
bottle-DEF stand chair-DEF topside
'The bottle is standing on the chair.'
*'The bottle is standing on the top of the chair.'
b. bútèlí-n fín bjá-n i sú.
bottle-DEF stand chair-DEF 3.SG topside
'The bottle is standing on the chair.'/
'The bottle is standing on the top of the chair.'

These examples show that the alternation between the versions of the adpositional phrase with and without a pronominal possessor is not semanti- 
cally vacuous. Recall that the compositional view predicts that the uses of the version with a pronominal possessor are a subset of the uses of the version without a pronominal possessor, since the latter version is underspecified. However, our data suggest the opposite pattern (we come back below to this apparent mismatch).

The semantic contrast evinced in (17) and (18) is well attested in languages that develop adpositions out of nouns encoding body parts. For instance, similar facts are reported for Mixtec (see Macauley 1993: 172ff.). In order to evaluate the relevance of these contrasts concerning grammaticalization, we need comparative evidence from the referential use of the same elements.

A similar semantic effect occurs when the locative nouns are used as arguments. (19a) is the version without a pronominal possessor which is now the unspecified version. (19b) illustrates the version with a pronominal possessor: the only reading is one in which the predicate holds for an inherent part of the spatial configuration of the referent encoded by the noun.

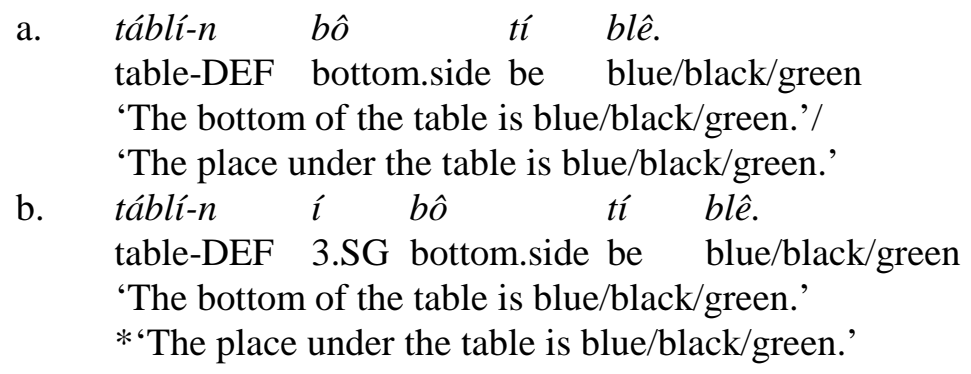

These examples provide evidence for a semantic difference between the nominal and the adpositional use of the locative nouns. In the nominal use, the version with a pronominal possession denotes a meronomic relation between the referent of the head noun and the referent of the dependent noun as exemplified in (19b), while the construction without a pronominal possessor is unspecified (see (19a)), exactly as predicted by the compositional account. In the adpositional use, exemplified in (17) and (18), the occurrence of pronominal possessors is desemanticized, i.e., it looses its capability to denote a meronomic relation. The version without pronominal possession is in the adpositional use restricted to the abstract meaning, i.e. the meaning that we except to find for adpositional elements. 
So far we examined compositional uses of locative nouns and we found a systematic alternation between a version with possessive morphology and a version without. Moreover, we were able to identify minimal pairs in which these two versions are not synonymous and we claimed that the version with possessive morphology displays evidence for desemanticization in the adpositional uses of locative nouns. Next to the compositional uses of the locative nouns in adpositional function, these elements display a large number of uses that arise through metaphorical extension. When a spatial noun relates to a temporal or further abstract concept, the partwhole interpretation encoded through the pronominal possessor cannot apply literally.

The noun sin 'back.side' denotes the spatial region of 'posterior'. However, it also occurs as a comitative, which is illustrated by (20a). This abstract meaning of the noun is only available for the version without possessive morphology. Evidence for this restriction is given in (20b): the version with possessive morphology only allows the concrete spatial interpretation of the noun sin 'back.side'.

$$
\begin{aligned}
& \text { a. kwàsí tò kòfí sîn. } \\
& \text { Kouassi play Kofi back.side } \\
& \text { 'Kouassi plays (together) with Kofi.' } \\
& \text { b. kwàsí tò kòfí } i \text { sîn. } \\
& \text { Kouassi play Kofi 3.SG back.side } \\
& \text { 'Kouassi plays behind Kofi.' } \\
& \text { *'Kouassi plays (together) with Kofi.' }
\end{aligned}
$$

The noun $b \hat{o}$ 'under' denotes the spatial concept of inferior. However, in the context of motion verbs it may be used to introduce complex targets of motion. This use is exemplified in (21). The use of the possessive pronoun in (21) would denote the literal region of the bottom part of the dance, which would not make sense in this context.

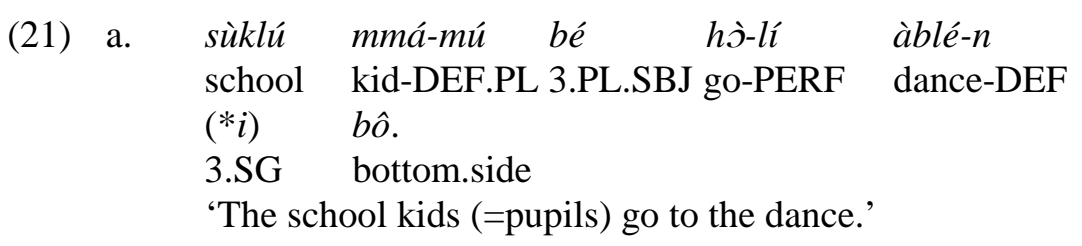


The choice of adposition is idiomaticized for some nouns denoting typical places. Hence, the noun fje 'field' typically combines with the adposition $s u ́$ 'topside' and the noun gwá 'public.place' with the adposition bo 'bottom.side'. The choice of adposition is not transparent in these cases. Crucially, the idiomatic meaning is only available for the versions without a pronominal possessor, as illustrated in (22a) and (23a).

$\begin{array}{llll}\text { a. } & n & k \sigma & m \bar{a} n \text { fjē sú. } \\ & \text { 1.SG.SBJ.CL } & \text { go.IMP } & \text { NEG field topside }\end{array}$ 'I do not go to the field.'

b. $\quad n$

$$
\text { kó mān fjēe i sú. }
$$

1.SG.SBJ.CL go.IMP NEG field 3.SG topside

'I do not go to the top of the field.'

*'I do not go to the field.'

(23)
a.
kó mān gwá
bô.
1.SG.SBJ.CL go.IMP NEG public.place bottom.side
'I do not go to the market.'
b. ń ḱ mān gwá i bô.
1.SG.SBJ.CL go.IMP NEG market 3.SG bottom.side
'I do not go below the market.'
*'I do not go to the market.'

The data from non-compositional uses and from idiomatic uses complicate the facts. Since we found evidence for the desemanticization of the construction with pronominal possessors, we could hypothesize that this construction would be eligible in all contexts. However, the incompatibility of this construction with non-compositional and idiomatic uses shows that this is not the case. How do these generalizations fit together?

We assume that the complex data pattern from the use of adpositions in Nànáfwê is an effect of grammaticalization applying to certain constructions. Pronominal possessors are excluded in the uses of adpositional phrases that do not involve a meronomic relation between the head noun and the dependent noun. Pronominal possessors are desemanticized in the adpositional use of locative nouns, i.e. in the context of a particular syntactic construction, but not in other contexts. If these properties are the result of diachronic developments, we may speculate that the development of the idiomatic and non-compositional uses took place at a diachronic stage at which pronominal possessors were not yet desemanticized. 


\section{V-relators}

\subsection{Preliminaries}

Verbs are the second source of adpositions in West African languages (see Heine, Claudi, and Hünnemeyer 1991: 140-141). The grammaticalization path originates in a stage $S_{1}$ at which two verbs are in a coordination construction, usually without a coordinative conjunction ('asyndeton' or 'covert coordination'). In many of the languages of this linguistic area, serial verbs develop from this construction as illustrated in stage $S_{2}$ below. This stage involves the development of a complex head containing two verbs that denotes a single event. Within the serial verb construction of the type $\mathrm{V}_{1} \mathrm{~V}_{2} \mathrm{NP}$, the second verb $\mathrm{V}_{2}$ may develop to an adposition which reflects the final stage of this grammaticalization path.

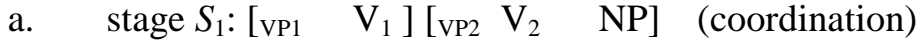
b. stage $\left.S_{2}:\left[\begin{array}{llll}\mathrm{vP} & {\left[\mathrm{v} \mathrm{V}_{1}\right.} & \mathrm{V}_{2}\end{array}\right] \mathrm{NP}\right] \quad$ (serial verb)
c. stage $S_{3}$ : [vP $\mathrm{V}$ [AdpP Adp NP]] (verb and adposition)
d. $\quad S_{1}>S_{2}>S_{3}$

Assuming that the verbs that are eligible for this process have an argument slot, there is no change in the governing properties of the head of the embedded constituent: the complement of the verb in the initial stage $S_{1}$ is the complement of the adposition at the final stage $S_{2}$. The change affects the categorical status of the head. Evidence for the change V > Adp is the fact that the $\mathrm{V}$ is not (part of) the head of the predicate anymore; a concomitant change may be the loss of verbal inflection (see Lehmann 1995b: 104).

The development from verb to adposition is already attested in several Benue-Kwa languages (see Lord 1993: 29). For instance, the verb gye 'take' in Twi is used for the concept of 'except' in which case it does not take tense/aspect, negation and agreement. In Ewe, some verbs developed to prepositions and lost their capability of conjugation. However, loss of inflection is not a necessary condition: the verb gyaw 'leave' in Twi is used with the meaning 'without' retaining its inflectional properties (see Lord 1993: 141-147). Aim of this section is to examine the locative verbs of Nànáfwê and to seek for evidence for the grammaticalization of $\mathrm{V}$-relators.

Typical V-relators that enter this grammaticalization path are verbs that encode spatial relations (static, allative, ablative, perlative). Table 2 presents the verbs that are used for the encoding of such relations in Nànáfwê. 
Their occurrence in syntactic constructions has already been introduced in example (14).

Table 2. V-relators in Nànáfwê

\begin{tabular}{ll}
\hline spatial relation & verb \\
\hline static & $o$ 'be.located' \\
allative 1 & $k o$ 'go' \\
allative 2 & $\mathcal{F} u$ 'arrive' \\
allative 3 & $b a$ 'arrive, come' \\
perlative & sin 'pass' \\
ablative & fin 'leave' \\
\hline
\end{tabular}

These verbs occur in combination with other motion verbs as is exemplified in (25). In the following, we examine two constructions that may be instantiated through several verbs of the corresponding paradigms. The first is a construction of 'manner + relation', encoded both through separate verbs as illustrated in (25a). The second is a construction of 'relation + relation', encoded through the combination of two verbs of the list in Table 2 , as exemplified in (25b).

$$
\begin{array}{llll}
\text { a. } & \text { kòfi nàntí kó dímbókrô. } \\
\text { Kofi walk go Dimbokro } \\
\text { 'Kofi walks to Dimbokro.' } \\
\text { b. } \quad \text { kòfi fin dímbókrô kó ábìfān. } \\
\text { Kofi leave Dimbokro go Abidjan } \\
\text { 'Kofi goes from Dimbokro to Abidjan.' }
\end{array}
$$

Only the verbs of motion are involved in serial verb constructions such as those exemplified in (25). The static locative verb does not form corresponding constructions, since static relations are expressed through the absence of an exponent of spatial relation (the use of the locative verb in static adjuncts is attested in Ewe, see Heine, Claudi, and Hünnemeyer 1991). This is illustrated in (26a) by means of a static locative adjunct that modifies a non-spatial event and in (26b) by a static locative adjunct that modifies a verb of manner of motion (this example correspond to the construction of motion verbs with dative PPs in German). 

(26) a. nànnán tóntòn-ní dwó-n (*ó) grandfather cook-PFV yam-DEF be.located swā sîn. house back.side 'The grandfather cooked the yam behind the house.' b. kòfi nàntí (*ó) dímbókrô nú. Kofi walk be.located Dimbokro inside 'Kofi walks inside Dimbokro.'

\subsection{Verb serialization}

The first question is whether the examples in (25) constitute serial verbs or instances of covert coordination. 'Covert coordination' is the concatenation of either clausal or embedded constituents without any conjunction (asyndeton). The main criterion for the distinction between covert coordination and verb serialization is argument sharing (see Stewart 2001:6-11 for an outline of the different approaches in recent literature). Serial verbs are assumed to be concatenated parts of the same head and to share the same arguments. Furthermore, covert coordination is expected to be fully compositional and to be applicable to any elements of a particular constituent type, while verb serialization may involve several restrictions as to the exact types of verbs that may form part of a series or to their linear order.

The property of argument sharing applies to the verb constructions in (25) only with respect to the subject constituents, which is not unambiguous evidence since covert coordination may also apply to predicate constituents. The verb nàntí 'walk' cannot take a noun as a complement, as shown in (27), hence argument sharing is excluded for the locative complement of (24a). In (24b), the two motion verbs have clearly different complements.

(27) *kòfi nàntí dímbókrô.

Kofi walk Dimbokro

(intended) 'Kofi walks to Dimbokro.'

However, these constructions display some non-compositional properties that are not expected to occur in covert coordination constructions. First, the order of the involved verbs is irreversible. The verb encoding manner of motion has to precede the verb encoding the spatial relation in (25a) 
(compare (28a), and the verb encoding ablative relation has to precede the verb encoding allative relation in (25b) (compare (28b).

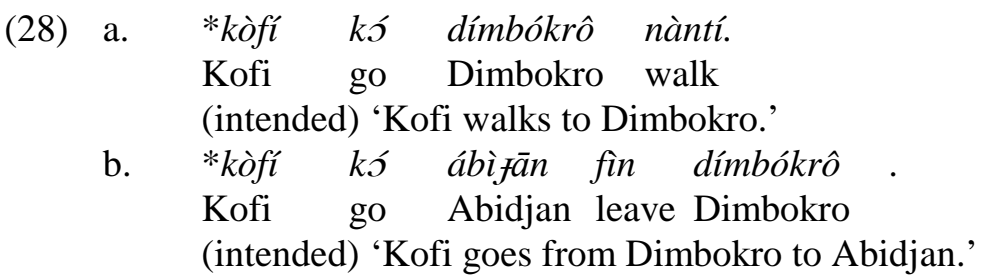

The ungrammaticality of (28a-b) is not the result of general rhetorical constraints on the linearization of particular event types, but it is associated with the particular type of construction in which the two verbs are involved. The ungrammatical linearizations in (28) are possible in (29), which illustrates clear cases of covert coordination (since subject sharing does not apply). The contrast in the grammaticality of (29) versus (28) implies that the constructions displaying subject sharing involve some conventionalized linearization properties.

$$
\begin{aligned}
& \text { a. kòfí kó dímbókrô ò nàntí. } \\
& \text { Kofi go Dimbokro 3.SG.SBJ.CL walk } \\
& \text { 'Kofi goes to Dimbokro (and) he walks.' } \\
& \text { b. kòfí kó ábìfān ̀̀ fin dímbókrô . } \\
& \text { Kofi go Abidjan 3.SG.SBJ.CL leave Dimbokro } \\
& \text { 'Kofi goes to Abidjan (and) he leaves Dimbokro.' }
\end{aligned}
$$

Further evidence comes from the inflectional properties of the verbs in the constructions with subject sharing. The tense properties of the verbs involved in this construction have to be uniform (see (30a)), the corresponding inflectional markers may be affixed to either verb without any semantic difference (see (30b-e)), and marking of these inflectional properties on both verbs invokes the intuition of redundancy (see (30f-g)). Taken together, this data suggests that both verbs form a complex verb head in a construction of subject sharing which is accompanied by inflectional affixes once.

$$
\begin{array}{lllll}
\text { a. } \quad \begin{array}{l}
* \\
\text { Koffi }
\end{array} \text { sú nàntí àa } & \text { kó dímbókrô. } \\
\text { (intended) 'Kofi is walking and will go to Dimbokro.' }
\end{array}
$$



b. kòfí sú nàntí kó dímbókrô.
Kofi PROG walk go Dimbokro
'Kofi is walking to Dimbokro.'
c. kòfí àá fin dímbókrô kś ábìtān.
Kofi FUT leave Dimbokro go Abidjan
'Kofi will go from Dimbokro to Abidjan.'
d. kòfí nàntí sú kó dímbókrô.
Kofi walk PROG go Dimbokro
'Kofi is walking to Dimbokro.'
e. kòfí fin dímbókrô àá kó ábìfān.
Kofi leave Dimbokro FUT go Abidjan
'Kofi will go from Dimbokro to Abidjan.'

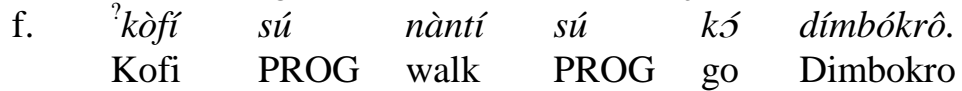
(redudant) 'Kofi is walking to Dimbokro.'
g. 'kòfí àá fin dímbókrô àá kó ábìfān.
Kofi FUT leave Dimbokro FUT go Abidjan
'Kofi will go from Dimbokro to Abidjan.'

Further evidence comes from negation. The negation particle $m \bar{a} n$ is placed immediately after the verbal head in Nànáfwê, as exemplified in (31a). In constructions of 'manner + relation', the negative particle has to follow the last verb, as shown through the contrast between (31b) and (31c). The scope of negation in (31b) is not restricted to the preceding verb, but to the complex event, i.e., this expression may be followed either by the continuation '.. but he walks to Abidjan' or by the continuation '.. but he runs to Dimbokro', i.e. both verbs may be negated separately. This evidence supports the view that the manner verb and the relation verb form a complex event head in this construction.

(31) a. kòfí kó mān dímbókrô.

Kofi go NEG Dimbokro

'Kofi does not go to Dimbokro.'

b. kòfí nàntí kó mān dímbókrô.

Kofi walk go NEG Dimbokro

'Kofi does not walk to Dimbokro.'

c. *kòfí nàntí mān kó dímbókrô.

Kofi walk NEG go Dimbokro

(intended) 'Kofi does not walk to Dimbokro.' 
Exactly the same data pattern appears in the 'relation + relation' construction. The negative particle has to appear right adjacent to the second verb and its scope does not only relate to the destination of the movement, but to the entire complex event.

$$
\begin{array}{ll}
\text { a. kòfi fin dímbókrô kó mān ábì̄ān. } \\
\text { Kofi leave Dimbokro go NEG Abidjan } \\
\text { 'Kofi goes from Dimbokro to Abidjan.' } \\
\text { b. } \quad \text { *òfi fin mān dímbókrô kó ábì fān. } \\
\text { Kofi leave NEG Dimbokro go Abidjan } \\
\text { (intended) 'Kofi goes from Dimbokro to Abidjan.' }
\end{array}
$$

Adverbs display properties similar to the negation particle. As mentioned in section 2, adverbs are placed after the verbal complements in Nànáfwê. Examples (33a-b) show that the manner adverb $n d \bar{\varepsilon} d \bar{\varepsilon}$ 'rapidly' may be placed either after the manner verb or after the complement of the relation verb. This evidence shows that the dependent noun is not reanalyzed as complement of the first verb in which case the adverb could not occur in the position exemplified in (33a). The crucial evidence is however the interpretation of these examples. There is no discrete semantic difference between (33a) and (33b), i.e. it is not the case that the adverb in the former construction modifies the manner of motion and in the latter construction the event of reaching the destination. Both verbs constitute a complex event head that may be modified as a unit.

$$
\begin{aligned}
& \text { a. kòfí nàntí ndēdé kó dímbókrô. } \\
& \text { Kofi walks rapidly go Dimbokro } \\
& \text { 'Kofi walks rapidly to Dimbokro.' }
\end{aligned}
$$

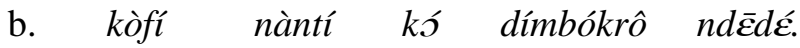

$$
\begin{aligned}
& \text { Kofi walks go Dimbokro rapidly } \\
& \text { 'Kofi walks rapidly to Dimbokro.' }
\end{aligned}
$$

This fact is exemplified through the contrast between (34a) and (34b) for the 'relation + relation' construction. An interpretation in which the temporal adverb either relates only to the origin of motion or only to the target of motion is not available. The adverb obligatorily relates to the complex event. 

(34) a. kòfí fin dímbókrô ndé kś ábìfān.
Kofi leave Dimbokro early go Abidjan
'Kofi goes early from Dimbokro to Abidjan.'
b. kòfi fin dímbókrô kó ábìzān ndé.
Kofi leave Dimbokro go Abidjan early
'Kofi goes early from Dimbokro to Abidjan.'

In conclusion, this section provided rich evidence that the two constructions involving V-relators, namely the 'manner + relation' construction and the 'relation + relation' construction, are serial verb constructions. The linearization of verbs in these constructions is conventionalized and cannot be altered under the condition of subject sharing. The encoding of inflectional categories and of negation as well as the interpretational properties of adverbs show that the two verbs involved in either construction form a complex head.

\subsection{Evidence for grammaticalization to adpositions}

The next question is whether there is evidence for grammaticalization of the V-relators in these constructions to adpositions. The evidence we presented in the previous section clearly supports the view that this is not the case. The loss of inflection that is reported for verbs turning to adpositions in other languages of the area (see for instance Ewe or Akan in Lord 1993: 141-147) does not apply for Nànáfwê, see in particular examples (30e-g). Example (35) shows that the second verb of motion may be accompanied by the perfective suffix.

$$
\begin{array}{lccc}
\text { kòfi } & \text { nàntí } & \text { hò-lí } & \text { dímbókrô. } \\
\text { Kofi } & \text { walk } & \text { go-PFV } & \text { Dimbokro } \\
\text { 'Kofi walked to Dimbokro.' }
\end{array}
$$

Furthermore, the distributional properties of the verbs in the previous section provide clear evidence that a reanalysis V>Adp did not take place in Nànáfwê. Adverbs are placed after verb complements, hence if the second verb was reanalyzed as an adposition, the placement of the adverb after the first verb would be excluded, which is not the case as demonstrated in (33a) and (34a). In the same vein, if the ' $V_{2}$ NP' string were an adpositional phrase, then it should be possible for the negative particle to 
precede this constituent, which also renders an ungrammatical serialization as (31c) shows. On the basis of this evidence, we conclude that V-relators are verbs in Nànáfwê that also occur in serial verb constructions.

\section{Further differences between $\mathrm{N}$-relators and V-relators}

The previous sections lead to the conclusion that $\mathrm{N}$-relators and V-relators do not have the same categorical status. N-relators are nouns that display the properties of an incipient stage of grammaticalization to adpositions. V-relators are still at the first stage of the cross-linguistically attested grammaticalization path: they are serial verbs. That the two types of relators belong to distinct grammatical categories is indicated by their word order properties: V-relators precede the dependent noun, while $\mathrm{N}$-relators follow it. If our estimation of the different categorical status is on the right track, then we should be able to identify further distributional differences between the two categories.

A first difference relates to the properties of the governing slot. V-relators are essentially verbal heads, hence they may govern adverbs, as illustrated in (36a). This is not expected to apply to N-relators (see data from further languages of the same area in Heine, Claudi, and Hünnemeyer 1991). Example (36b) shows indeed that placement of the deictic adverb in the position of dependents of the N-relator results in ungrammaticality.

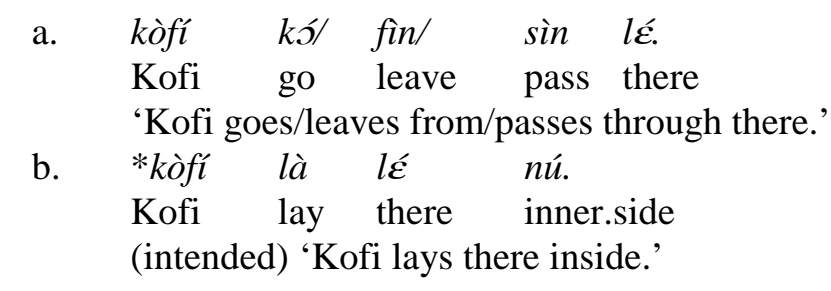

Evidence from cleft sentence formation shows that the string ' $\mathrm{V}_{\text {head }} \mathrm{NP}$ ' and the string ' $\mathrm{NP} \mathrm{NP}_{\text {head }}$ ' are not constituents of the same type. Example (37a) illustrates a canonical sentence with a positional verb, an N-relator and its nominal dependent. (37b-c) illustrate two different possibilities of forming cleft sentences: either through extraction of the dependent noun or through extraction of the whole verb complement including both the $\mathrm{N}$-relator and its dependent. 
(37)
a. bútèlí-n fín bjá-n sú. bottle-DEF stand chair-DEF topside 'The bottle is standing on the chair.'
b. bjá-n sú jé bútèlín fín ò. chair-DEF topside REL bottle-DEF stand PRES 'It is on the chair that the bottle is standing.'
c. bjá-n jé bútèlí-n fín sú ò. chair-DEF REL bottle-DEF stand topside PRES 'It is the chair that the bottle is standing on.'

These possibilities of extraction are not available for ' $\mathrm{V}_{\text {head }} \mathrm{NP}$ ' strings. The examples in (38) are the clefted counterparts of (25a) and show that it is not possible to separate the two verbal heads of a serial verb construction, while it is possible to extract the nominal complement.
a. *kó dímbókrô jé kòfí nàntí ò. go Dimbokro REL Kofi walk PRES 'It is to Dimbokro that Kofi is walking.'
b. dímbókrô jé kòfí nàntí kó j. Dimborko REL Kofi walk go PRES 'It it Dimborko that Kofi is walking to.'

The same phenomenon is illustrated in (39) for the clefted counterparts of (25b). It is not possible to extract the second verb while its complement may be extracted.
a. *kó ábìfān jé kòfí fin dímbókrô ò. go Abidjan REL Kofi leave Dimbokro PRES (intended) 'It is to Abidjan that Kofi goes from Dimbokro.'
b. ábìfān jé kòfí fin dímbókrô kó ò. Abidjan REL Kofi leave Dimbokro go PRES 'It it to Abidjan that Kofi goes from Dimbokro.'

\section{Conclusions}

This investigation began with the question whether there is evidence for grammaticalization to adpositions in Nànáfwê. Knowing from further West African languages that adpositions develop out of nouns and verbs, we 
undertook a systematic examination of the distributional and interpretational properties of two classes of spatial relators in our object language: $\mathrm{N}$-relators and V-relators.

$\mathrm{N}$-relators are nouns that denote parts of spatial configurations (typically termed 'body part' nouns). These nouns are at the incipient stage of a grammaticalization process. When used for the introduction of verbal complements, their use with pronominal possessors looses its semantic transparency and their denotation indicates a process of desemanticization. Furthermore, in particular constructions such as some conventionalized constructions with particular nominals or some metonymic uses they may not combine anymore with a possessive pronoun as in their nominal usage. On the semantic layer, the grammaticalized uses of these elements do not denote parts of spatial configurations but spatial regions.

$\mathrm{V}$-relators are verbs that also occur in verb series. We provided rich evidence for the distributional properties of these elements that unambiguously shows that in particular constructions they form a complex verb head together with other verbs. Both verbs encode a unique event that may be modified once as we illustrated by means of restrictions on the use of aspectual morphology, on the placement and scope of negation, on the placement and interpretation of adverbs. However, we argued that there is no evidence for a further development on this grammaticalization path, which would lead from (parts of) serial verbs to local adpositions. This argument was based on the fact that these elements are fully inflected and on the positional properties of adverbs and negation that indicate that these verbs (together with their complement NPs) are not reanalyzed as verbal complements. Furthermore, the extraction possibilities suggest that the two verbs in these constructions form a complex head that cannot be separated and that the second verb together with its complement does not form a unique constituent.

The empirical relevance of our investigation is that it figures out the syntactic properties of Nànáfwê that provide us with evidence how the incipient stages of grammaticalization processes of nouns and verbs to adpositions look like. The theoretical significance of our findings is that they provide evidence for the independence between function and form in grammaticalization processes. In functional viewpoint, both $\mathrm{N}$-relators as well as V-relators in Nànáfwê do not essentially differ from prepositions in familiar European languages. The corresponding constructions in several languages of the area where Nànáfwê is spoken underwent a grammaticalization process that led to the development of genuine adpositions in these 
languages (see, e.g. Ewe in Heine, Claudi, and Hünnemeyer 1991). The corresponding elements in Nànáfwê are either in a very incipient stage of this process ( $\mathrm{N}$-relators) or have not entered this process yet ( $\mathrm{V}$-relators).

\section{Notes}

1. In order to maintain consistency in the glosses, we use the morphemic translation that applies to the lexical element (noun or verb) throughout its uses (also in the adpositional ones).

2. In plural, independent and cliticized forms only differ in their tonal properties.

3. The use of the pronominal possessor is obligatory with plural possessors (see Creissels and Kouadio 1977, Bohoussou 2008: 21).

4. The region 'exterior', which is the antonym to 'interior' is not encoded by a member of this paradigm. This concept may be rendered either by the locative noun for 'posterior' in metonymical use or by more complex expressions.

\section{References}

Ahoua, Firmin

1996 Prosodic Aspects of Baule: with special reference to the German of Baule speakers. Köln: Köppe.

Bohoussou, Amani

1996 La structure interne de l'énoncé verbal du Nanafwe. Mémoire de maîtrise, Université de Cocody (Abidjan).

2008 L'énoncé complexe du Nanafwe. Unterschleissheim: Lincom.

Bohoussou, Amani, and Stavros Skopeteas

2005 En nanafwe. In Typologie de la syntaxe connective, Christos Clairis, Claudine Chamoreau, Denis Costaouec, and Françoise Guérin (eds.), 155-169. Rennes: Presses Universitaires de Rennes.

Carteron, Michel

1966 Essai de grammaire de la langue "baoulé". Bocanda.

Creissels, Denis, and N'guessan Kouadio

1977 Description phonologique et grammaticale d'un parler baoulé. Abidjan: Institut de Linguistique appliqué (Linguistique africaine, 59).

1979 Les tons du baoulé: parler de la région de Toumodi. Abidjan: Université d'Abidjan, Institut de linguistique appliquée. 
Creissels, Denis, and Jérémie Kouadio

2007 Resumptive pronouns in ditransitive constructions: The case of Baule. Handout presented in the Conference on Ditransitive Constructions, Max-Planck Institute for Evolutionary Anthropology, Leipzig 23-25 November 2007.

Gross, Marcel

1967 Essai pour une phonologie du baoulé. Paris: CEDEV/CNRS (Bulletin de la SELAF, 2).

Heine, Bernd

1989 Adpositions in African languages. Linguistique Africaine 2, 77-127.

Heine, Bernd, Ulrike Claudi, and Friederike Hünnemeyer

1991 Grammaticalization: A Conceptual Framework. Chicago/London: The University of Chicago Press.

Heine, Bernd, and Mechthild Reh

1984 Grammaticalization and Reanalysis in African languages. Hamburg: Buske.

Kouadio, Jérémie

2000 Les séries verbales en baoulé: questions de morphosyntaxe et de sémantique. Studies in African Linguistics 29 (1): 75-90.

Larson, Martha

2002 Baule SVCs: Two distinct varieties of missing objects'. In Proceedings of the Legon/Trondheim Linguistics Project Annual Colloquium, M.E. Dakubu and E. Osam (eds.), 87-109.

2005 The Empty Object Construction and related phenomena. Ph.D. dissertation, Cornell University.

Leben, William R., and Firmin Ahoua

1997 Prosodic domains in Baule. Phonology 14: 113-132.

Lehmann, Christian

1990 Towards lexical typology. In Studies in Typology and Diachrony, William Croft, Denning Keith, and Suzanne Kemmer (eds.), 161185. Amsterdam: Benjamins.

1992 Yukatekische lokale Relatoren in typologischer Perspektive. Zeitschrift für Phonetik, Sprachwissenschaft und Kommunikationsforschung 45: 626-641.

1995a Raumkonstruktion in funktionaler Sicht. Unpublished ms., University of Erfurt.

1995b Thoughts on Grammaticalization. Unterschleissheim: Lincom.

Lord, Carol

1993 Historical Change in Serial Verb Constructions. Amsterdam/Philadelphia: Benjamins. 
104 Amani Bohoussou and Stavros Skopeteas

Macauley, Monica

1993 A Grammar of Chalcatongo Mixtec. Berkeley: University of California Press.

Rennison, John R.

1997 Koromfe. London/New York: Routledge.

Rubba, Jo

1994 Grammaticalization as semantic change. A case study of preposition development. In Perspectives on Grammaticalization, William Pagliuca (ed.), 81-101. Amsterdam/Philadelphia: Benjamins.

Skopeteas, Stavros

2007 Semantic categorizations and reasoning in the domain of superposition. In Ontolinguistics: Correlations between Ontological Status and Linguistic Coding, Dietmar Zaefferer and Andrea Schalley (eds.), 331-356. Berlin/New York: Mouton De Gruyter.

Stewart, Osamuyimen Thompson

2001 The Serial Verb Construction Parameter. New York/London: Garland.

Svorou, Soteria

1986 On the evolutionary paths of locative expressions. Papers from the Annual Meeting of the Berkeley Linguistics Society 12: 515-527.

1993 The grammar of space. Amsterdam/Philadelphia: Benjamins.

Timyan, Judith

1977 A discourse-based grammar of Baule: The Kode dialect. Ph.D. dissertation, City University of New York.

1978 N wan yo: Cours de baoulé. Université d'Abidjan. 